\title{
THE EFFECT OF CITROVORUM FACTOR (FOLINIC ACID) ON MEGALOBLASTS IN VITRO
}

BY

\author{
SHEILA T. CALLENDER AND L. G. LAJTHA \\ From the Nuffield Department of Clinical Medicine, and the Department of Clinical \\ Pathology, Radcliffe Infirmary, Oxford
}

(RECEIVED FOR PUBLICATION MARCH 16, 1951)

Sauberlich and Baumann (1948) found that an unidentified factor present in refined liver extract was necessary for the growth of the organism Leuconostoc citrovorum 8081. The addition of large amounts of folic acid to the culture medium was shown to produce slow growth in the absence of liver extract, suggesting some relationship between folic acid and the unidentified citrovorum factor (C.F.). Since then evidence has gradually accumulated that the citrovorum factor or factors are biologically more active derivatives of folic acid. The citrovorum factor also appears to be identical with folinic acid, a naturally occurring substance found by Bardos, Bond, Humphreys, and Shive (1949) to support growth of Leuconostoc citrovorum under the conditions described by Sauberlich and Baumann.

The citrovorum factor is about a million times more active for Leuconostoc citrovorum than is folic acid (Shive, Bardos, Bond, and Rogers, 1950) and is far more effective than folic acid in the competitive reversal of the toxicity of folic acid antagonists for $L$. casei (Bond, Bardos, Sibley, and Shive, 1949), rats (Nichol and Welch, 1950a), and mice (Broquist, Stokstad, and Jukes, 1950 ; Brockman, Roth, Broquist, Hultquist, Smith, Fahrenbach, Cosulich, Parker, Stokstad, and Jukes, 1950). In the treatment of the megaloblastic anaemia of monkeys produced by dietary deficiency C.F. has been shown to be active in much smaller doses than folic acid (May, Sundberg, and Schaar, 1950). The increased C.F. excretion in the urine of folic-acid-deficient rats and normal man after folic acid intake suggests an in vivo conversion of folic to folinic acid (Sauberlich, 1949). Liver slices will bring about a similar conversion in vitro (Nichol and Welch, 1950b).

In experiments on bone marrow cultures from cases of untreated pernicious anaemia folic acid has been found to act directly on megaloblasts producing ripening of these cells to normoblasts (Rusznyák, Löwinger, and Lajtha, 1948 ; Lajtha, 1950). The evidence that C.F. is a biologically more active form of folic acid suggested further in vitro studies to determine whether megaloblasts can utilize the citrovorum factor.

\section{Methods}

Suspensions of bone marrow cells were cultured in a medium of $90 \%$ serum and $10 \%$ Ringer solution, both cells and sera being obtained from patients with untreated 
pernicious anaemia. To some cultures C.F. was added in a concentration of 0.1 or $0.01 \mu \mathrm{g}$. per ml. medium; to others, refined liver extract ("anahaemin") which had been assayed microbiologically for C.F. equivalent. Two samples of liver extract were used, one having a C.F. equivalent of $0.3 \mu \mathrm{g}$. per ml., the other $0.2 \mu \mathrm{g}$. per $\mathrm{ml}$. Of the first extract $0.03 \mathrm{ml}$. was added to each ml. culture medium, i.e., the same volume as the " pernaemon forte" liver extract previously found to produce ripening of megaloblasts in vitro (Lajtha, 1950) giving a C.F. equivalent of $0.01 \mu \mathrm{g}$. per ml. medium. Of the second extract $0.03 \mathrm{ml}$. of a 1 in 100 dilution was added to each ml. medium, this concentration being chosen as being near to the pharmacological dose in untreated pernicious anaemia. This gave a C.F. equivalent of $0.07 \mu \mu \mathrm{g}$. per ml. medium

In two experiments the ripening effect of folic acid in a concentration of $0.1 \mu \mathrm{g}$. and $0.01 \mu \mathrm{g}$. per ml. medium respectively was compared with the effect of the C.F. at the same level. After 48 hours (in one experiment after 24 hours) films of the marrow cultures were stained and differential counts made on the nucleated red cells by each of us independently.

The results of the experiments are shown in Tables I and II.

TABLE I

The Effect of Folinic Acm on Megaloblasts in vitro

\begin{tabular}{|c|c|c|c|c|c|}
\hline \multirow{3}{*}{$\begin{array}{l}\text { Experiment } \\
\text { No. }\end{array}$} & \multicolumn{5}{|c|}{ Megaloblasts per 100 Nucleated Red Cells } \\
\hline & \multirow{2}{*}{$\begin{array}{l}\text { Initial } \\
\text { State }\end{array}$} & \multicolumn{4}{|c|}{ 48-Hour Cultures in } \\
\hline & & $\begin{array}{l}\text { P.A. } \\
\text { Serum }\end{array}$ & $\begin{array}{c}\text { P.A. Serum }+ \\
0.1 \mu \mathrm{g} . \text { C.F. } / \mathrm{ml} \text {. }\end{array}$ & $\begin{array}{c}\text { P.A. Serum }+ \\
0.01 \mu \mathrm{g} . \text { C.F. } / \mathrm{ml} \text {. }\end{array}$ & $\mid \begin{array}{c}\text { P.A. Serum }+ \\
0.07 \mu \mu \text { g. C.F. } / \mathrm{ml}\end{array}$ \\
\hline $81 \mathrm{a}$ & 32.0 & 35.0 & 14.0 & & $38.0^{*}$ \\
\hline $\begin{array}{l}81 b \\
82 \\
84 a \\
85 \\
86\end{array}$ & $\begin{array}{l}32.0 \\
36.0 \\
42.0 \\
44.0 \\
44.0\end{array}$ & $\begin{array}{l}63.0 \\
31.5 \\
29.5 \\
17.5 \\
19.0\end{array}$ & $\begin{array}{r}20.0 \\
16.5 \\
14.0 \\
9.5\end{array}$ & $\begin{array}{l}15.0 \\
8.5^{*}\end{array}$ & 20.0 \\
\hline
\end{tabular}

*C.F. equivalent in "anahaemin."

TABLE II

COMparison Between Folic ACID AND Folinic ACID ACtion in vitro

\begin{tabular}{|c|c|c|c|c|c|}
\hline \multirow{3}{*}{$\begin{array}{l}\text { Experiment } \\
\text { No. }\end{array}$} & \multicolumn{5}{|c|}{ Megaloblasts per 100 Nucleated Red Cells } \\
\hline & \multirow{2}{*}{$\begin{array}{l}\text { Initial } \\
\text { State }\end{array}$} & \multicolumn{4}{|c|}{ Cultures in } \\
\hline & & $\begin{array}{l}\text { P.A. } \\
\text { Serum }\end{array}$ & $\begin{array}{l}\text { P.A. Serum } \\
+ \text { Folic Acid }\end{array}$ & $\begin{array}{l}\text { P.A. Serum } \\
\quad+\text { C.F. }\end{array}$ & Remarks \\
\hline $84 a$ & 42.0 & & 43.0 & 26.5 & $0.1 \mu \mathrm{g}$. medium. $24 \mathrm{hr}$. \\
\hline 85 & 44.0 & 17.5 & 19.5 & 8.5 & $\begin{array}{l}0.01 \mu \mathrm{g} \text {. medium. } 48 \mathrm{hr} \text {. } \\
\text { culture }\end{array}$ \\
\hline
\end{tabular}

\section{Discussion}

It is clear that the C.F. has a similar ripening effect on megaloblasts in marrow culture to that found in previous experiments with folic acid. It also is able to overcome the action of the inhibitor present in serum from untreated pernicious 
anaemia (Lajtha, 1950 ; Thompson, 1950). The effective concentration of folic acid used before was $2 \mu \mathrm{g}$. per ml. medium. In the present experiments $1 / 20$ and $1 / 200$ of this amount appeared to be ineffective. In contrast, similar concentrations, i.e., 0.1 and $0.01 \mu \mathrm{g}$. per ml. medium, of the C.F. showed a significant ripening effect. This provides further evidence that the C.F. is a biologically more active form of folic acid.

The previous finding that $0.03 \mathrm{ml}$. of a 1947 batch of refined liver extract (" pernaemon forte," Organon) ripened megaloblasts in vitro (Lajtha, 1950) now requires reconsideration. The effect could not be due to $B_{12}$ since crystalline $B_{12}$ was found to be inactive in vitro. The possibility that $\mathrm{B}_{12}$ in liver extract was modified in some way, giving a haemopoietic factor active in vitro similar to that found in normal serum, was suggested. There is good evidence for the existence of such a form of $\mathbf{B}_{12}$, but the processes involved in the preparation of liver extracts would destroy its activity (Callender and Lajtha, to be published). Alternatively the ripening effect could have been due to the presence of folic acid or the C.F. None of the batch of "pernaemon forte" is available for assay for these substances. Another refined liver extract ("anahaemin ") has, however, been tested. The folic acid content of the "anahaemin" was negligible, but the C.F. equivalent in $0.03 \mathrm{ml}$. of extract was $0.01 \mu \mathrm{g}$., which was sufficient in $1 \mathrm{ml}$. of medium to produce ripening of megaloblasts. At a lower concentration (C.F. equivalent $0.02 \mu \mu \mathrm{g}$. per ml. medium) closer to the estimated pharmacological dose of liver extract, no ripening occurred. As pure C.F. this level was also ineffective. This suggests that the effect previously noted with "pernaemon forte" was due to the C.F. content of the extract.

\section{Summary}

Pure citrovorum factor has a direct ripening effect on megaloblasts in bone marrow culture.

Weight for weight citrovorum factor appears to be more effective than folic acid in ripening megaloblasts in vitro.

We are indebted to Dr. T. H. Jukes, of the Lederle Research Laboratories, U.S.A., for supplies of the citrovorum factor and to Dr. G. Spray, Oxford, for the microbiological assays.

\section{REFERENCES}

Bardos, T. J., Bond, T. J., Humphreys, J., and Shive, W. (1949). J. Amer. chem. Soc., 71, 3852. Bond, T. J., Bardos, T. J., Sibley, M., and Shive, W. (1949). Ibid., 71, 3852.

Brockman, J. H., Roth, B., Broquist, H. P., Hultquist, M. E., Smith, J. M., Fahrenbach, M. J., Cosulich, D. B., Parker, R. P., Stokstad, E. L. R., and Jukes, T. H. (1950). Ibid., 72, 4325.

Broquist, H. P., Stokstad, E. L. R., and Jukes, T. H. (1950). J. biol. Chem., 185, 399.

Callender, S. T., and Lajtha, L. G. To be published.

Lajtha, L. G. (1950). Clin. Sci., 9, 287.

May, C. D., Sundberg, R. D., and Schaar, F. (1950). J. Lab. clin. Med., 36, 963.

Nichol, C. A., and Welch, A. D. (1950a). Proc. Soc. exp. Biol., N.Y., 74, 403.

(1950b). Ibid., 74, 52 .

Rusznyák, S., Löwinger, S., and Lajtha, L. G. (1948). Hungarica Acta med., 1, 9.

Sauberlich, H. E. (1949). J. biol. Chem., 181, 467.

- and Baumann, C. A. (1948). Ibid., 176, 165.

Shive, W., Bardos, T. J., Bond, T. J., and Rogers, L. L. (1950). J. Amer. chem. Soc., 72, 2817.

Thompson. R. B. (1950). Clin. Sci., 9, 281. 
from the ganglion nodosum of the vagus nerve; in the second there were two separate tumours, one arising in the vagus nerve and the other in the carotid body of the opposite side; the third patient had an upper anterior mediastinal tumour; and in the fourth case there were three independent tumours, involving respectively the ganglion nodosum, carotid body, and adventitia of the aortic arch. Microscopically, these tumours all resembled those of the carotid bodies and those of the glomus jugulare. The carotid body, the glomus jugulare, the paraganglion intravagale, and the aortic-arch bodies all have a similar structure and are probably similar chemoreceptors; they form a " paraganglionic system" which is quite distinct from the chromaffin tissues. The development of similar, and not infrequently multiple, tumours from these several structures is thus readily understandable. This is the first report of tumours of the aortic bodies in man, though Bloom has described such tumours in the dog (Arch. Path., 1943, 36, 1). The present paper contains a full bibliography, and also includes some excellent photomicrographs of the aortic and vagal paraganglia. $R$. A. Willis.

Prognosis in Carcinoma of the Breast. Bцоом, H. J. G. (1950). Brit. J. Cancer, 4 , 259.

A series of 470 cases of carcinoma of the breast treated at the Middlesex Hospital were graded according to the degree of tubule formation, uniformity in size, shape, and staining of the nuclei, and the number of hyperchromatic nuclei and mitoses.

By combining this method with the Manchester system of classification, a more accurate prognosis can be given than by classification alone. Certain tumours, if they are of a low histological grade, may be associated with a better prognosis even if they have reached Stage III than other more malignant grades still confined to the breast in Stage I ; this finding is a strong argument in favour of the au.hor's system of grading.

Possible fallacies in grading and staging are discussed.
Errors in staging arise from involvement of lymph nodes (as in the internal mammary chain) not revealed clinically or post-operatively; and from the fact that lymph nodes clinically enlarged may not be actually involved in tumour, and conversely that nodes involved may not be palpable clinically. Supraclavicular lymph-node involvement, undetectable either clinically or after operation, is another factor which might vitiate the accuracy of staging. Nevertheless, the author concludes that the system which he proposes is the best possible means of classification available, and he makes out a well-argued case that the universal adoption of this combined clinico-pathological method will lead to more accurate assessment of different methods of treatment.

H. J. B. Atkins.

\section{Unilateral Renal Cortical Necrosis and Unilateral Benign and Malignant Nephrosclerosis associated with Contra- lateral Artery Occlusion : Report of a Case. Aronson, S. M., and Sampson, M. C. (1951). Arch. Path., 51, 30.}

The case is described of a man of 52 who complained of cough, fever, headache, and loss of weight. At necropsy the left kidney showed the changes of benign and malignant hypertension and gross cortical necrosis. The right kidney was normal. The renal artery on the right side was grossly sclerotic, with marked reduction of the lumen, which was terminally thrombosed. There were old and recent infarcts in the heart, a nontuberculous cavity in the lung, and [?] viral hepatitis. The pituitary gland was normal.

It is thought that the hypertension was due to ischaemia of the right kidney, and that this was unaffected by the cortical necrosis because its functional activity was low and its nutritional demands adequately supplied by the capsular anastomotic vessels. D. M. Pryce.

Correction.-Dr. Callender writes that in her paper "The Effect of Citrovorum Factor (Folinic Acid) on Megaloblasts in vitro" (J. clin. Path., 4, 204) the abbreviation $\mu \mu \mathrm{g}$. was used for millimicrograms instead of $\mathrm{m} \mu \mathrm{g}$. 